\title{
Children as decision makers: the Hayman Park community project in Aotearoa New Zealand
}

\author{
Pornchanuch Chumpunuch ${ }^{1}$, Margaret Hinepo Williams ${ }^{2}$ \\ 199/19 Moo 16, Tambon Thasae, Amphoe Thasae, Chumporn, Thailand \\ 86140, Email: pornchanuch.c@gmail.com, Phone: +66 980163306
}

${ }^{2}$ School of Public Health and Interdisciplinary Studies, Auckland University of Technology, University South Campus, 640 Great South Road, Manukau, Auckland, New Zealand 2025, Email: margaret.williams@aut.ac.nz.

\begin{abstract}
Introduction: Our study explores the efficacy of community consultation in redesigning the Hayman Park playground from a community perspective. Hayman Park is located in Manukau City centre in the south of New Zealand's capital city, Auckland. It has a mixed community of Pasifika, Māori and other ethnic groups with a younger demographic than average.

Methods: We used a qualitative approach to examine participants' perceptions. Of the 27 adults $(\mathrm{N}=27)$ who participated, three $(\mathrm{n}=3)$ were available for one-on-one, face-to-face interviews post project. Two transcripts recorded during focus group activities involving 27 children $(\mathrm{N}$ $=27)$ were also analysed. We found that six $(\mathrm{n}=6)$ children expressed opinions during their involvement. Their views, alongside those of adults, were parsed into emergent categories and themes.
\end{abstract}

Results and Discussion: We identified three themes: health and well-being; community and individual needs; and the effectiveness of community partnership. Responses from both adults and children indicated that participants felt they had achieved better health and well-being. Feedback showed significant gains in knowledge and awareness. However, participants wanted a deeper relationship with project leaders.

Conclusion: We conclude that the Hayman Park project is a good example of how involving local communities in designing the spaces they live in can engender positive outcomes. However, the project did not fulfil participants' desire for more meaningful engagement with the leading stakeholders.

Keywords: Community partnership, Children as effective partners, Children decision-makers, Children's physical activity, playgrounds, New Zealand

Pornchanuch Chumpunuch and Dr. Margaret Hinepo Williams are affiliated with Public Health at Auckland University of Technology, Aotearoa New Zealand. For correspondence, contact Pornchanuch Chumpunuch. (Lecturer), School of Nursing, Walailak University, Thailand. pornchanuch.c@gmail.com 


\section{Introduction}

Building a healthy community environment can encourage local people to lead an active lifestyle. Individual health is associated with community members' abilities to participate, and the social support of whole-whānau (family) participation can be enhanced by providing playgrounds in communities. This type of play space is positively associated with children's physical activity levels, social integration, well-being and development through role-playing (Bundy et al., 2017; Mayfield et al., 2017). Playground equipment provides significant opportunities for children to engage in fullbody physical activity (Delidou, Matsouka, \& Nikolaidis, 2015).

Community-designed playgrounds are closely associated with whole-family well-being (Quigg, Reeder, Gray, Holt, \& Waters, 2012). Upgrading community playgrounds can significantly increase children's mean physical activity levels, especially youngsters with a low body mass index (BMI) (Quigg et al., 2012). However, community playground improvements can also significantly limit children's physical activity levels and the number of children who use the play area (Bohn-Goldbaum et al., 2013). This can occur when parents hold negative perceptions about playground equipment safety (Bohn-Goldbaum et al., 2013). Equipment safety is a key factor that may restrict the playgrounds that parents will let their children use (Huynh, Demeter, Burke, \& Upperman, 2017).

\section{Community partnership principles}

A key component of community-based projects is active community partnership, as demonstrated in the "Kohikohi Kitea Kohikohi Kōrero: Hayman Park Engagement with Children and Whānau (family)" project (Andajani-Sutjahjo, Dickinson, Parry, Vodanovich, \& Liew, 2016). The community partnership approach creates healthy local environments where parents' reservations about safety are eased through their involvement (Brennan, Brownson, Kelly, Ivey, \& Leviton, 2012). Collaboration with external partners enable communities to build their capacity through empowerment (Yeneabat \& Butterfield, 2012).

To be effective, community project organisers must recruit partners who can provide the needed resources (Cullen, Bowden, \& Spronken-Smith, 2012). Useful partners include community members who understand the problems in their communities and can therefore act as advocates; effective community members have mana (high standing) in their communities, and can communicate local views effectively (Bopp, Fallon, Bolton, \& Kahl, 2012).

Merging a researcher's knowledge with community members' know-how creates an effective project strategy. It is vital that researchers and public sector workers collaborate with community members to better understand local viewpoints, especially when working together on redesigning a focal point in a community, such as a playground (Arroyo-Johnson et al., 2016). The Hayman Park venue in Manukau, South Auckland, New Zealand, is a good example of one such local community hub (Andajani-Sutjahjo et al., 
2016). To achieve an effective redesign of Hayman Park's playground, Auckland Council and the Ōtara Papatoetoe Local Board (Manukau's governing bodies in charge of public spaces) mandated a researcher to join forces with local Manukau parents, caregivers, children and extended family. This approach enabled authorities to find out about participants' ideas (Andajani-Sutjahjo et al., 2016).

There are some challenges to the community partnership approach. The first challenge is to balance power between community participants and external stakeholders (Donaldson \& Daughtery, 2011; El Ansari, Oskrochi, \& Phillips, 2010). Although a community partnership needs people with a broad range of skills to work together, balancing the authority of researchers or professionals with the local experiences of community members is not so easy (Di Pietro \& Illes, 2016).

Clearly, grassroots communities should be involved in activities that support health (WHO, 2013). In fact, empowerment through involvement leads to good health (King, Curran, \& McPherson, 2013). Empowerment can be achieved through sharing educational resources, knowledge, skills and the ability to communicate about a common outcome. This was the approach taken by local authorities in redesigning the Hayman Park playground (Andajani-Sutjahjo et al., 2016).

\section{Children as partners}

In community projects like playground design, acknowledging young people's ideas is just as important as acknowledging adults' perceptions: Goodwin and Young (2013) found that children provide more insightful suggestions than adults about how to improve community spaces in which they are interested. Youth participation in community development gives younger generations an increased sense of confidence in making decisions, too (Saridar-Masri, 2016). The youth-centric model works particularly well in tailoring playgrounds to meet the needs of their primary users, children, and indirectly, the adults in the community who supervise their play.

Youth are described by scholars as active planners with different perspectives from adults; children are also better than adults at knowing their own needs (Carroll, Witten, Donovan, \& Kearns, 2015). Younger people can provide adults with new ideas, such as how to create a more child-friendly neighbourhood (Carroll et al., 2015). When children are involved in community partnership projects, they get an opportunity to develop skills in negotiation and planning in a social environment that includes them (Saridar-Masri, 2016).

Recognising children's ideas during the design process means playgrounds are better utilised (Marouf, Che-Ani, Tawil, Johar, \& Tahir, 2015). Children's involvement is strongly associated with their subsequent enjoyment of the play space, especially the playground equipment (Lozanovska \& Xu, 2013). Their needs being met is also associated with higher physical activity levels (Boonzajer-Flaes, Chinapaw, Koolhaas, van Mechelen, \& Verhagen, 2016). 
Formally adopting the youth-centric approach is important because, when the rules of engagement are made clear from the beginning, children have a safe space in which to express their opinions (Boonzajer-Flaes et al., 2016). Setting the stage for youth involvement prevents adults from underestimating children's capacity to be effective decision-making partners (Derr \& Tarantini, 2016; van Bijleveld, Dedding, \& Bunders-Aelen, 2014). However, adults' engrained attitudes of dismissal remain a primary challenge when engaging children in community partnership projects (Elsley, 2004).

\section{Hypothesis}

To partially address this challenge, we explored the effectiveness of involving children in redesigning the Hayman Park playground. Because perception often defines judgements of "effectiveness" (Draaisma, 2017), we chose to evaluate the perceptions of both children and adults who participated. The original project was about consulting with park visitors and other adults such as parents but not children. This study focused on what both adults and children desired in the playground.

We expected to uncover a positive correlation between children's involvement and community well-being.

\section{Methods}

We used a qualitative approach to explore both adults' and children's experiences because this method was well aligned with our goal of gaining a deeper understanding of participants' inner thoughts (Starks \& Trinidad, 2007).

\section{Participant demographics}

Participants in the playground redesign project included people $(\mathrm{N}=27)$ of Māori, Pasifika (Pacific Island), Pākehā (European), Samoan, Niuean, Korean, Chinese, Indonesian, Pakistani, Syrian, German and Russian descent (Andajani-Sutjahjo et al., 2016). The researcher organising the redesign purposefully recruited participants from multiple ethnic groups because the South Auckland's Manukau district is one of the most culturally diverse areas of New Zealand (Andajani-Sutjahjo et al., 2016; Auckland City Multi-Ethnic Council, n.d.).

Of the 27 adults participating in the original project, only three $(n=3)$ women were available to assist with the current research. Post project, we conducted one-on-one, face-to-face interviews with them. To understand youth perspectives, we analysed transcripts produced during the redesign process (Andajani-Sutjahjo et al., 2016). Of the 27 youth participants (11 girls and 16 boys, students 7-12 years of age) who were involved, we analysed six $(n=6)$ voices based on the relevance of their feedback. 


\section{Interview design}

Interview questions were designed to elicit information about adults' perceptions of community partnerships. Questions asked were:

1. "How well did the playground consultation project raise your awareness about health and well-being?"

2. "What needs were met for community members participating in the project?"

3. "If you could make changes to better meet the health and well-being needs of your community playground, what would these be?"

These three questions were also used to assess the children's recorded responses. This research used the same question with adults to capture their voices and perceptions.

\section{Data collection}

The children's focus group as well as the adult responses were important primary sources of data. One-to-one interviews were held with three women in person, and they took 1 hour each. Participants consented to the interviews being audio-recorded, and notes were also taken to provide a secondary record. The three adults were a subset of the 27 adults involved in the Hayman Park playground design.

We initially analysed all children's focus group transcripts. Transcripts in which children did not express views about the project were discarded. Two of the 10 transcripts yielded feedback about the project. Of the 11 student participants whose responses were recorded in these two transcripts, six voices gave clearly articulated opinions.

\section{Limitations and discussion about children's research}

Photo, video and camera mediums are often described as non-intrusive and friendly for capturing the child's voice and experience through the research process (Blazek, M., \& Hrañová,2012). One research study indicated that the urban developer gave children opportunity to share their dream design of a child-friendly neighbourhood in Australia through drawing and discussion (Bradbury-Jones \& Taylor ,2015). The "Kohikohi Kitea Kohikohi Kōrero: Hayman Park Engagement with Children and Whānau (family)" project showed that the inclusion of Minecraft games, virtual game, camera and laptop encouraged children to share their views and experiences towards designing their new playground through photos (AndajaniSutjahjo, Dickinson, Parry, Vodanovich, \& Liew, 2016). However, the challenge in this type of research is to train and work with children. The process is time consuming and requires much resourcing such as money and staff to purchase the tools and then for staff to teach the children about how to use the tool (Melona,2013). 


\section{Data analysis}

We used a general inductive approach for analysis because this method is aligned with extracting meaning from qualitative data (Thomas, 2006). First, we reviewed interview and focus group transcripts until we were familiar with the content. Second, we divided texts into segments and worked through the segments to understand how the context aligned with our research objective. Third, we divided text segments into "meaning units". Fourth, themes emerging from the text segments were grouped into broader categories (Thomas, 2006). Interview transcripts were provided to the research participants to review.

\section{Ethics approval}

We obtained ethics approval from the Auckland University of Technology (AUT) Ethics Committee (AUTEC) on May 3rd, 2016 (AUTEC reference number 16/105). 


\section{Results}

The demographics of the Hayman Park research project are set out in Table 1. The categories and themes that emerged from interviews with adults (Table 2) and children's focus group transcripts (Table 3) overlapped in the health and well-being category.

Table 1. Demographics of the Hayman Park research project participants.

\begin{tabular}{|c|c|c|c|}
\hline Participant ID & $\begin{array}{l}\text { Age } \\
\text { (years) }\end{array}$ & $\begin{array}{l}\text { Gender } \\
(\mathrm{F} / \mathrm{M})\end{array}$ & Role of participant \\
\hline Woman 1 & - & $\mathrm{F}$ & $\begin{array}{l}\text { Researcher commissioned by the Auckland } \\
\text { Council / Ōtara Papatoetoe Local Board }\end{array}$ \\
\hline Woman 2 & 30 & $\mathrm{~F}$ & $\begin{array}{l}\text { A caregiver for one of the child participants, } \\
\text { also a participant herself }\end{array}$ \\
\hline Woman 3 & 44 & $\mathrm{~F}$ & $\begin{array}{l}\text { A local community member, not a parent of a } \\
\text { child participant }\end{array}$ \\
\hline Girl 1 & 11 & $\mathrm{~F}$ & Child participant \\
\hline Girl 2 & 8 & $\mathrm{~F}$ & Child participant \\
\hline Girl 3 & 11 & $\mathrm{~F}$ & Child participant \\
\hline Girl 4 & 12 & $\mathrm{~F}$ & Child participant \\
\hline Boy 1 & 12 & M & Child participant \\
\hline Boy 2 & 10 & M & Child participant \\
\hline
\end{tabular}

Notes. We interviewed three adult participants $(\mathrm{n}=3)$ involved in the original project, and we collected and analysed two children's focus group transcripts. Of the 11 students whose responses were recorded in the two transcripts we analysed, only six students $(n=6)$ gave responses that were relevant to our research objectives. The symbol - means that the participant did not wish to disclose her age.

Abbreviations. F, female; ID, identification; M, male. 
Table 2. Categories and themes emerging from interviews with adults who participated in the Hayman Park playground redesign project.

\begin{tabular}{|c|c|}
\hline Categories & Themes \\
\hline \multirow[t]{4}{*}{ Health and well-being } & $\begin{array}{l}\text { The importance of increased physical } \\
\text { activity playground redesign afforded }\end{array}$ \\
\hline & $\begin{array}{l}\text { Social well-being derived from project } \\
\text { "ownership" }\end{array}$ \\
\hline & $\begin{array}{l}\text { A sense of belonging/inclusion through } \\
\text { participation }\end{array}$ \\
\hline & A sense of value and being valued \\
\hline \multirow[t]{2}{*}{ Community needs } & $\begin{array}{l}\text { A need for more involvement from the } \\
\text { beginning }\end{array}$ \\
\hline & $\begin{array}{l}\text { A need for someone to listen at a deeper } \\
\text { level }\end{array}$ \\
\hline \multirow[t]{4}{*}{$\begin{array}{l}\text { Effectiveness } \\
\text { partnership }\end{array}$} & $\begin{array}{l}\text { Maintaining a balance of knowledge } \\
\text { between community and professional leads } \\
\text { to effective partnerships }\end{array}$ \\
\hline & $\begin{array}{l}\text { Children as effective partners gained mana } \\
\text { (standing in the community) }\end{array}$ \\
\hline & $\begin{array}{l}\text { Raised awareness among people in the } \\
\text { community about the value of public } \\
\text { spaces and partnerships results from } \\
\text { working together }\end{array}$ \\
\hline & $\begin{array}{l}\text { Knowing the real needs of the community } \\
\text { remains a challenge }\end{array}$ \\
\hline
\end{tabular}

Notes. Of the total 27 adult participants $(\mathrm{N}=27)$, we interviewed three women $(\mathrm{n}=3)$ who were available within the short timeframe imposed by research parameters.

Abbreviations. $\mathrm{N}$, total participants available; $\mathrm{n}$, subgroup interviewed.

Table 3. Categories and themes emerging from children's focus group transcripts produced during the Hayman Park playground redesign project.

\begin{tabular}{|c|c|}
\hline Category & Themes \\
\hline \multirow{2}{*}{ Health and well-being } & Sense of being valued \\
\hline & Sense of belonging \\
\hline
\end{tabular}


The relationships between themes and categories can be depicted visually (Figure 1).

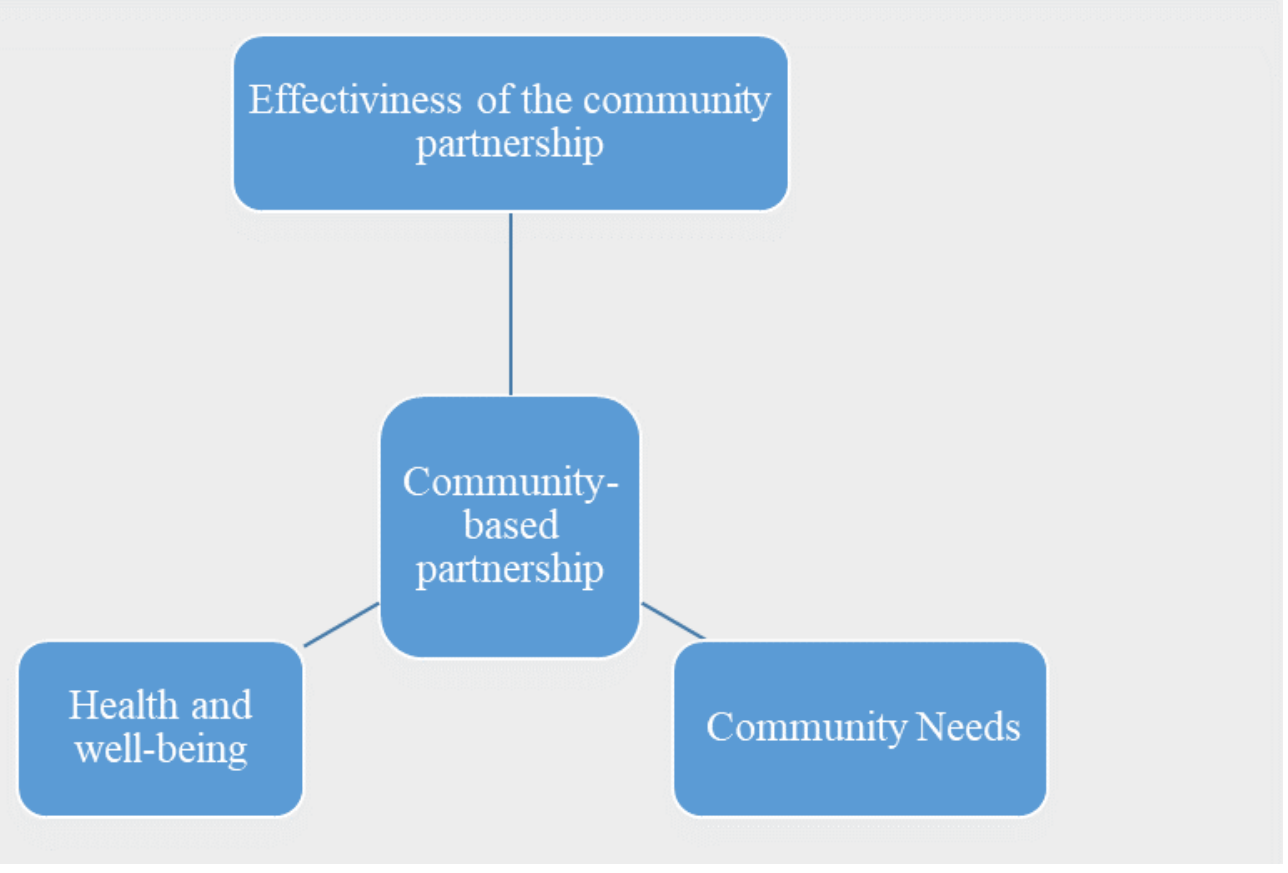

Figure 1 . The three categories stemming from the community partnership that was the Hayman Park playground redesign project.

\section{Adult perspectives}

Interviewees stated that the Hayman Park project should have included the Auckland Council, and that the concept of partnership was desirable but not a norm.

"With this kind of project, because it's involving the community, it does make sense that you have to work with different stakeholders. The park belongs to the Auckland Council ... they acknowledge that the park's deficient; so, [they] need to get involved." (Woman 1)

“... I suppose it's one of the very few times that people in the community [were] able to have a direct say as to what, or how, a playground is to be designed ..." (Woman 3)

Interviewees felt that the primary benefits were increased physical activity, for both adults and children.

"... If you talk about health and well-being, you can do exercise [at the playground]. But there's also leisure activities ... you're not just sitting and watching movies or things like that, you're 
physically active. And that includes the whole family from different age groups." (Woman 1)

The sense of well-being was perceived to be a result of children's happiness.

"Just being creative and getting the kids to use their own initiative, or their own imagination to create opportunities for themselves, rather than coming from an adult ... was fantastic." (Woman 2)

The positive effects included a perceived balance between community member's knowledge and that of the project leaders.

"Working with the researchers was ... fantastic in the sense that you know you both have something, that the balance of grassroots, as well as academia, could come together to deliver." (Woman 3)

"You're getting a lot of people involved in it. There's not only one problem, there's multiple ones and we see it from different points of view." (Woman 2)

Adults were able to acknowledge children as equal partners, too.

"I think our project could have an impact in terms of we are showing that, look, we can get the children's voices, we can get pictures from the children; and children know it's their community. And don't underestimate children!" (Woman 1)

Raised awareness arose from adults' ability to create a good social space for their children.

"I think it [the project] gave an awareness of the community, like what is out there, or what can we do as community members to make it a better place, or a more fun and a safer place for kids." (Woman 2)

\section{Youth perspectives}

Children wanted to play in the playground because their ideas had helped to shape it.

"I would play on it because we are designing it and we're putting the things we like in it so it'll be a good place to come to." (Boy 1)

Children felt they were important because they were given the opportunity to have some input. When asked if they enjoyed being part of the original research,

"Yes, because they asked for our help." (Girl 1) 
"Yes because they were asked for their input." (Girl 2)

"Yes! It's very exciting because, it's a day where I can have a map of, the knowledge to build a park." (Boy 2)

"Um I like doing this because I haven't really done this before, and it's interesting to help a park that is done by me." (Girl 4)

One of the child participants felt important because he made something different for the city.

"Yup I'm enjoying it because I'm making changes to the city." (Boy 1)

\section{Discussion}

\section{The positives}

"Physical activity" as a theme emerged from the interviews. In fact, playgrounds are renowned for facilitating fitness and activity (Potwarka, Kaczynski, \& Flack, 2008; Prellwitz \& Skär, 2007). Interviewees described enhanced social well-being when their children were encouraged to use their imaginations to create the playground "on paper"; children were allowed into the adult world. Clearly, Manukau's youth derived social benefits from making decisions in a community that included them (Malone, 2013). They also gained decision-making skills (Saridar-Masri, 2016).

Adults felt a sense of belonging because their children felt valued. Community members gained a sense of "ownership" via the partnership (De Marco et al., 2014; King et al., 2013). The sense of being valued was important for the participants because their community was respected by external stakeholders. These benefits were described by children at the time of the project, and by adults post project, indicating consistency over time. Clearly, sharing knowledge allowed community stakeholders to gain a sense of shared investment (Sutton \& Kemp, 2002).

Maintaining the balance of knowledge was important to adults who helped redesign the Hayman Park playground. Previous studies corroborate the idea that community partnerships are powerful strategies for integrating knowledge between community members and external "experts" (Jagosh et al., 2015; Thompson \& Hood, 2016). This balance is particularly important when designing pivotal social areas, such as playgrounds (Arroyo-Johnson et al., 2016).

Children became effective partners when adults recognised their real needs (Farmer, Gage, Kirk, \& Edgar, 2016; Tipene-Leach et al., 2013). Adults placed youth in a creative leadership role, and Hayman Park's child designers provided good input on improving their playground; from that, they gained the ability to make the community theirs (Derr \& Kovács, 2017; Goodwin \& Young, 2013). The sense that community members had gained the mana (standing) to create a fun and safe space increased awareness 
across the local Manukau, South Auckland rohe (district). Both children and adults became conscious of their own capabilities, similar to the empowerment participants have experienced in other community partnerships (Eghbalnia et al., 2013).

\section{The negatives}

The Hayman Park project did not satisfy the Manukau community's need for deeper connections and ongoing involvement. Adults wanted to invite all partners with a stake, not just a few, in accordance with Cullen et al. (2012), who found that to create a truly effective community partnership, all partners must be involved, especially if they have the needed resources, which in this case, the silent partner, Auckland Council, had. Inviting the full quota of community members is especially important when multiple ethnicities share the same public spaces, as in Manukau (O'Mara-Eves et al., 2015).

The need for someone to listen and then act is also imperative. The Hayman Park project appears to have met the needs of the community during the design phase, but the actual rebuild did not involve community members. For community participants to feel they have been listened to, they must also exercise power in the relationship, and that means finishing the job (E1 Ansari et al., 2010).

\section{Conclusion}

A community-based partnership approach to redesigning public recreational spaces can enhance participating partners' health and wellbeing. Benefits are perceived by community members to include more potential enjoyment of physical activity in the space, improved social wellbeing derived from the act of participation, a sense of belonging, and a sense of being valued as equals. These gains were apparent in the Hayman Park playground project. A balance of knowledge and power encouraged participants, including children, to form an effective partnership with external stakeholders. Moreover, the partnership allowed external researchers to explore the community's unmet needs, i.e., continuing and meaningful involvement. Looking to the future it is recommended that research with children requires patience to meet both the child's age appropriate cognitive and physical abilities. This can be achieved by providing tools of engagement such as games and activities that are easy to use, fun and interactive as noted in this study. Expanding on these strategies is likely to extend participation of the child, the researcher and other key stakeholders. 


\section{References}

Andajani-Sutjahjo, S., Dickinson, A., Parry, D., Vodanovich, S., \& Liew, T. (2016). Kohikohi kitea kohikohi kōrero: Hayman Park engagement with children and whānau. Retrieved from https: / / moam.info/kohikohi-kitea-kohikohi-korero-hayman-park_59e779c01723dd2fabeea5b7.html

Arroyo-Johnson, C., Milam, L., Ackermann, N., Komaie, G., Goodman, M. S., Woodward, K., \& Hipp, J. A. (2016). Still separate, still unequal: Social determinants of playground safety and proximity disparities in St. Louis. Journal of Urban Health, 93(4), 627-638. https: / / doi.org/10.1007/s11524-016-0063-8

Auckland City Multi Ethnic Council. (n.d.). Welcome to Manukau. Retrieved July 25, 2021 from https: / / multiculturalnz.org.nz/Auckland+City+Multi+Ethnic+Coun $\underline{\text { cil }}$

Blazek, M., \& Hraňová, P. (2012). Emerging relationships and diverse motivations and benefits in participatory video with young people.

Children's Geographies, 10(2), 151-168.

http://dx.doi.org/10.1080/14733285.2012.667917

Bohn-Goldbaum, E. E., Phongsavan, P., Merom, D., Rogers, K., Kamalesh, V., \& Bauman, A. E. (2013). Does playground improvement increase physical activity among children? A quasi-experimental study of a natural experiment. Journal of Environmental \& Public Health, 109841-109841. https://doi.org/10.1155/2013/109841

Boonzajer-Flaes, S. A., Chinapaw, M. J., Koolhaas, C. M., van Mechelen, W., \& Verhagen, E. A. (2016). More children more active: Tailored playgrounds positively affect physical activity levels amongst youth. Journal of Science and Medicine in Sport, 19(3), 250-254. https: / /doi.org/10.1016/j.jsams.2015.03.001

Bopp, M., Fallon, E. A., Bolton, D. J., \& Kahl, D. (2012). Engaging community partners to develop a culturally relevant resource guide for physical activity and nutrition. Ethnicity and Disease, 22(2), 231238.

Bradbury-Jones, C., \& Taylor, J. (2015). Engaging with children as coresearchers: Challenges, counter-challenges and solutions. International Journal of Social Research Methodology, 18(2), 161173.

https: / / doi.org/ 10.1080/13645579.2013.864589

Brennan, L. K., Brownson, R. C., Kelly, C., Ivey, M. K., \& Leviton, L. C. (2012). Concept mapping: Priority community strategies to create changes to support active living. American Journal of Preventive 
Medicine, 43(5, Supplement 4), S337-S350.

https: / /doi.org/10.1016/j.amepre.2012.07.015

Bundy, A., Engelen, L., Wyver, S., Tranter, P., Ragen, J., Bauman, A., . . . Naughton, G. (2017). Sydney playground project: A clusterrandomized trial to increase physical activity, play, and social skills. Journal of School Health, 87(10), 751-759. https: / /doi.org/10.1111/josh.12550

Carroll, P., Witten, K., Donovan, P., \& Kearns, R. (2015). Kids in the city: Children's use and experiences of urban neighbourhoods in Auckland, New Zealand. Journal of Urban Design, 20(4), 417-436. https: / / doi.org/10.1080/13574809.2015.1044504

Cullen, N., Bowden, A., \& Spronken-Smith, R. (2012). Partnering between a geography department and a community initiative to provide a wind resource assessment for the Blueskin Bay region, Otago, New Zealand. New Zealand Geographer, 68(1), 49-61. https: / / doi.org/10.1111/j.1745-7939.2012.01220.x

De Marco, M., Kearney, W., Smith, T., Jones, C., Kearney-Powell, A., \& Ammerman, A. (2014). Growing partners: Building a communityacademic partnership to address health disparities in rural North Carolina. Progress in Community Health Partnerships: Research, Education, and Action, 8(2), 181-186. https: / / doi.org/10.1353/cpr.2014.0021

Delidou, E., Matsouka, O., \& Nikolaidis, C. (2015). Influence of school playground size and equipment on the physical activity of students during recess. European Physical Education Review, 22(2), 215-224. https://doi.org/10.1177/1356336X15598790

Derr, V., \& Kovács, I. G. (2017). How participatory processes impact children and contribute to planning: A case study of neighborhood design from Boulder, Colorado, USA. Journal of Urbanism, 10(1), 2948. doi:10.1080/17549175.2015.1111925

Derr, V., \& Tarantini, E. (2016). "Because we are all people": Outcomes and reflections from young people's participation in the planning and design of child-friendly public spaces. Local Environment, 21(12), 1534-1556.

https: / / doi.org/ 10.1080/13549839.2016.1145643

Di Pietro, N., \& Illes, J. (2016). Closing gaps: Strength-based approaches to research with Aboriginal children with neurodevelopmental disorders. Neuroethics, 9(3), 243-252. https: / /doi.org/ 10.1007/s 12152-016-9281-8

Donaldson, L. P., \& Daughtery, L. (2011). Introducing asset-based models of social justice into service learning: A social work approach. Journal of Community Practice, 19(1), 80-99. https: / / doi.org/ 10.1080/10705422.2011.550262 
Draaisma, D. (2017). Perception: Our useful inability to see reality. Nature, 544(7650), 296. https://doi.org/10.1038/544296a

Eghbalnia, C., Sharkey, K., Garland-Porter, D., Alam, M., Crumpton, M., Jones, C., \& Ryan, P. H. (2013). A community-based participatory research partnership to reduce vehicle idling near public schools. Journal of Environmental Health, 75(9), 14-19.

El Ansari, W., Oskrochi, R., \& Phillips, C. J. (2010). One size fits all partnerships? What explains community partnership leadership skills? Health Promotion Practice, 11(4), 501-514. https://doi.org/10.1177/1524839908318289

Elsley, S. (2004). Children's experience of public space. Children \& Society, 18(2), 155-164. https://doi.org/10.1002/CHI.822

Farmer, A., Gage, J., Kirk, R., \& Edgar, T. (2016). Applying communitybased participatory research to create a diabetes prevention documentary with New Zealand Māori. Progress in Community Health Partnerships: Research, Education, and Action, 10(3), 383390. https://doir.org/10.1353/cpr.2016.0045

Goodwin, S., \& Young, A. (2013). Ensuring children and young people have a voice in neighbourhood community development. Australian Social Work, 66(3), 344-357.

https://doi.org/10.1080/0312407X.2013.807857

Huynh, H., Demeter, N., Burke, R., \& Upperman, J. (2017). The role of adult perceptions and supervision behavior in preventing child injury. Journal of Community Health, 42(4), 649-655. https://doi.org/10.1007/s10900-016-0300-9

Jagosh, J., Bush, P. L., Salsberg, J., Macaulay, A. C., Greenhalgh, T., Wong, G., . . . Pluye, P. (2015). A realist evaluation of communitybased participatory research: Partnership synergy, trust building and related ripple effects. BMC Public Health, 15(1). https://doi.org/10.1186/s12889-015-1949-1

King, G., Curran, C. J., \& McPherson, A. (2013). A four-part ecological model of community-focused therapeutic recreation and life skills services for children and youth with disabilities. Child Care Health Development, 39(3), 325-336. https://doi.org/10.1111/j.13652214.2012.01390.x

Lozanovska, M., \& Xu, L. (2013). Children and university architecture students working together: a pedagogical model of children's participation in architectural design. CoDesign, 9(4), 209-229. https: / / doi.org/ 10.1080/15710882.2012.693187

Malone, K. (2013). "The future lies in our hands": Children as researchers and environmental change agents in designing a child-friendly neighbourhood. Local Environment, 18(3), 372-395. https://doi.org/10.1080/13549839.2012.719020 
Marouf, N., Che-Ani, A. I., Tawil, N. M., Johar, S., \& Tahir, M. M. (2015). Development of designing criteria in children's urban play space in Iran - Review of literature. Journal of Sustainable Development, 8(2), 113. https://doi.org/dx.doi.org/10.5539/jsd.v8n2p113

Mayfield, C. A., Child, S., Weaver, R. G., Zarrett, N., Beets, M. W., \& Moore, J. B. (2017). Effectiveness of a playground intervention for antisocial, prosocial, and physical activity behaviors. Journal of School Health, 87(5), 338-345. https://doi.org/10.1111/josh. 12506

O’Mara-Eves, A., Brunton, G., Oliver, S., Kavanagh, J., Jamal, F., \& Thomas, J. (2015). The effectiveness of community engagement in public health interventions for disadvantaged groups: A metaanalysis. BMC Public Health, 15(1), 129. https: / / doi.org/10.1186/s 12889-015-1352-y

Potwarka, L. R., Kaczynski, A. T., \& Flack, A. L. (2008). Places to play: Association of park space and facilities with healthy weight status among children. Journal of Community Health, 33(5), 344-350. https: / doi.org/10.1007/s10900-008-9104-x

Prellwitz, M., \& Skär, L. (2007). Usability of playgrounds for children with different abilities. Occupational Therapy International, 14(3), 144155. https: / /doi.org/10.1002/oti.230

Quigg, R., Reeder, A. I., Gray, A., Holt, A., \& Waters, D. (2012). The effectiveness of a community playground intervention. Journal of Urban Health, 89(1), 171-184. https://doi.org/10.1007/s11524011-9622-1

Saridar-Masri, S. (2016). Integrating youth in city planning: Developing a participatory tool toward a child-friendly vision of Eastern WastaniSaida [in press]. Alexandria Engineering Journal. https: / / doi.org/10.1016/j.aej.2017.01.023

Starks, H., \& Trinidad, S. B. (2007). Choose your method: A comparison of phenomenology, discourse analysis, and grounded theory. Qualitative Health Research, 17(10), 1372-1380. https: / / doi.org/10.1177/1049732307307031

Sutton, S. E., \& Kemp, S. P. (2002). Children as partners in neighborhood placemaking: Lessons from intergenerational design charrettes. Journal of Environmental Psychology, 22(1-2), 171-189. https://doi.org/10.1006/jevp.2001.0251

Thomas, D. R. (2006). A general inductive approach for analyzing qualitative evaluation data. American Journal of Evaluation, 27(2), 237-246. https://doi.org/10.1177/1098214005283748

Thompson, V. L. S., \& Hood, S. M. (Eds.). (2016). Academic and community partnerships and social change. In W. Tate, N. Staudt, \& A. Macrander (Eds.), The crisis of race in higher education: A day of 
discovery and dialogue (vol. 19) (pp. 127-149). Bingley, England: Emerald Group Publishing.

Tipene-Leach, D. C., Coppell, K. J., Abel, S., Pahau, H. L., Ehau, T., \& Mann, J. I. (2013). Ngati and healthy: Translating diabetes prevention evidence into community action. Ethnicity and Health, 18(4), 402-414. https://doi.org/10.1080/13557858.2012.754406

Van Bijleveld, G. G., Dedding, C. W., \& Bunders-Aelen, J. F. (2014). Seeing eye to eye or not? Young people's and child protection workers' perspectives on children's participation within the Dutch child protection and welfare services. Children \& Youth Services Review, 47, 253-259.

https://doi.org/10.1016/j.childyouth.2014.09.018

World Health Organization. (2013). Global action plan for the prevention and control of noncommunicable diseases 2013-2020. Retrieved from http://apps.who.int/iris/bitstream/10665/94384/1/97892415062 36_eng.pdf?ua $=1$

Yeneabat, M., \& Butterfield, A. K. (2012). "We can't eat road:" Asset-based community development and the Edam Sefer community Partnership in Ethiopia. Journal of Community Practice, 20(1/2), 134-153. https://doi.org/10.1080/10705422.2012.650121 